\title{
Restaurants of New York
}

The APSA readily acknowledges the humor of recommending a handful of restaurants from the dizzying variety of bistros, trattorias, sushi bars, pubs, cafés and diners that abound on every block in Manhattan. Nevertheless, we offer the following 34 suggestions. Most are located in midtown, near the Hilton and Sheraton Hotels;

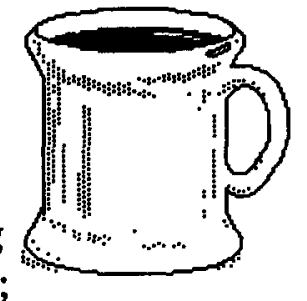
those with an asterisk $\left(^{*}\right)$ are somewhat farther away. As for prices, $\$=$ below $\$ 20.00$ for dinner; $\$ \$=\$ 21-39 ; \$ \$=$ over $\$ 40$. Lunch is generally less expensive.

We are wholly indebted to the Zagat 1994New York City Restaurant Survey. APSA Annual Meeting participants who are interested in purchasing a complete copy or participating in surveys in their cities are encouraged to call 1-800-333-3421.

\section{Bon appétit!}

Akbar

475 Park Ave. (between 57th and 58th St.), 838-1717, \$\$

Classic Indian dining, dark decor and an affordable lunchtime special.

\section{Al Bustan}

825 3rd Ave. (between 50th and 51st St.), 759-5933, \$\$

This Lebanese restaurant remedies the regrettable dearth of Middle East cuisine in midtown Manhattan.

\section{Allegria \\ MGM Building, 1350 Ave. of Americas (55th St.), 956-7755, \$\$ \\ Attractive decor and clients complement pizza and pasta in this Italian bistro.}

\section{American Festival Café}

20 W. 50th St. (Rockefeller Center Skating Rink), 246-6699, \$\$ $\$$ The view (not necessarily the food) accounts for the price. There won't be any skaters in September, but a drink by the fountain is worth the short walk from the hotel.

\section{Apple Restaurant *}

17 Waverly Pl. (between Greene and Mercer Sts.), 473-8888, $\$$

Original, new-wave, Health Food fare with drinks and karaoke? It's true and it's cheap.

\section{Bouley *}

165 Duane Street (between Greenwich and Hudson), 608-3852, \$\$\$

We might have created a "\$\$\$" category for New York's top-rated restaurant, but it's a fair price for exquisite French food, a lovely atmosphere and stellar service. When you call for a reservation, ask about the lunch special.

\section{Broadway Diner}

1726 Broadway (55th St.), 765-0909, \$

Quick, cheap, American diner food served in large portions.

\section{Carnegie Deli}

854 7th Ave. (between 54th and 55th Sts.), 757-2245, \$

Bring a big appetite for huge comed beef sandwiches and everything else you'd expect from a classic New York deli.

\section{Crèpes Suzette}

$363 \mathrm{~W}$. 46th Street (between 8th and 9th Aves.), 974-9002, \$\$

A comfortable bistro whose attentive owners spend time with their customers and on their cooking.

\section{Ellen's Stardust Diner}

1377 6th Avenue (56th St.), 307-7575, \$

Eggs, burgers and shakes for breakfast, lunch and dinner.

Grove *

314 Bleecker St. (Grove St.), 675-9463, \$\$

A mostly American menu with French and Italian inspirations makes dining in this attractive, friendly space an absolute pleasure.

\section{Harley Davidson Café}

1370 Ave. of Americas (56th St.), 245-6000, \$\$

As the Zagat's survey reports, this "duplex space-cum-bodyshop" is bound to draw crowds with its sampling of American roadtrip food.

\section{Il Tinello}

16 W. 56th St. (between 5th and 6th Aves,), 245-4388, \$\$\$

Price corresponds to quality in this quiet Northern Italian restaurant where the service is as good as the food.

\section{India Pavillion}

240 W. 56th St. (between Broadway and 8th Ave,), 489$0035, \$$

Spicy Indian food at low prices.

\section{Ipanema}

13 W. 46 th St. (between 5th and 6th Aves.), 730-5848, $\$ \$$

A rare outpost of Brazilian cuisine outside of Brazil, this new restaurant brings the camival spirit to Manhattan. 


\section{Where to Eat}

Jackson Hole

232 E. 64th St. (between 2nd and 3rd Aves.), 371-7187, \$

This midtown location is one of a few around town that serves sizable burgers with all their diner-style accoutrements.

Kabul Cafe

265 W. 54th St. (between Broadway and 8th Ave.), $757-2037$, \$\$

"Simple and tasty," this Afghan restaurant is on the cheap side of $\$ \$$ and is perfect before taking in a show.

\section{La Caridad *}

2199 Broadway (78th St.), 874-2780, \$

Cheap Chino-Latino tastes good and leaves you with a full stomach.

\section{Manhattan Ocean Club}

57 W. 58th St. (between 5th and 6th Aves.), 371-7777, \$\$\$

Universally praised as the best place for seafood in the City.

\section{Mee Noodle Shop}

922 2nd Avenue (49th Street), 888-0027, \$

Not exactly fine dining, but cheap, satisfying Chinese food.

\section{Nirvana}

30 Central Park South (between 5th and 6th Aves.), 486-5700, \$\$ Enjoy Indian food, memorable decorating and a wonderful view in this rooftop restaurant.

\section{Old Town Bar *}

45 E. 18th Street (between Broadway and Park Ave. South), 529$6732, \$$

This pub from New York of the 1890 s boasts great burgers and beer. If you can't get tickets for "The Late Show," look for David Letterman here.

Russian Tea Room

150 W. 57th St. (between 6th \& 7th Avenues), 265-0947, \$\$\$

Famous for Russian delicacies (though sometimes dismissed as a tourist trap), the Tea Room is also a good place to catch celebrities with their mouths full.

\section{Santa Fe}

72W. 69th St. (between Central Park West and Columbus Ave.), 724-0822, \$\$

Enjoy the warm surroundings of the Southwest right near Lincoln Center. The Tex-Mex menu goes down nicely with their potent margaritas.

\section{Sushi Zen}

57 West 46th St. (between 5th and 6th Aves.), 302-0707, \$\$

A peaceful midtown garden provides a perfect setting for sushi enthusiasts.

Tang Pavilion

65 W. 55th St. (between 5th and 6th Aves.), 956-6888, $\$ \$$

Clean and modern, this Chinese restaurant prepares virtually anything, made-to-order.

\section{Trionfo}

224 W. 51st St. (between Broadway and 8th Ave.), 262-6660, \$\$ Around the comer from the Sheraton Hotel, this friendly, littleknown Italian restaurant is perfect for a bite before a Broadway show.

\section{Viand}

673 Madison Ave. (between 61st and 62nd Sts.), 308-0828, \$

One Zagat's survey respondent reported enjoying the "best turkey sandwich on the planet" at this coffee shop and that assessment could only have been encouraged by friendly service.

Pho Pasteur Vietam * 85 Baxter St. (between Centre and Mulberry Sts.), 608-3656, \$

Relatively unknown, top-flight Vietnamese with great soups.

\section{Planet Hollywood}

140 W. 57th St. (between 6th and 7th Aves.), 333$7827, \$ \$$

This is the place to dine out with your children. It's lively, it serves pizza, fajitas and burgers and it is heaven for movie lovers.

Pongsri Thai Restaurant

244 W.48th St. (between Broadway and 8th Ave.), 582-3392, \$\$

Pleasant surroundings and tasty fare define this Theater District Thai place.

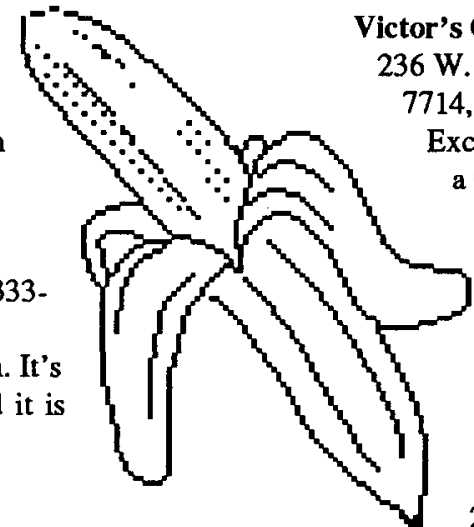

Victor's Cafe

W. 52nd St. (between Broadway and 8th Ave.), 586$714, \$ \$$

Exciting and spacious, this Theater District restaurant is a Cuban treat, boasting the best sangria around.

\section{Wolf's 6th Ave. Delicatessen}

101 W. 57th St. (6th Ave.), 586-1110, \$

Huge sand wiches, generous side dishes and New York-sized crowds can be found at this famous deli.

Wollensky's Grill *

205 E. 49th St. (3rd Ave.), 753-0444, \$\$

A cheaper and less harried way of getting a taste of the classic New York steakhouse (Smith \& Wollensky is next door). Good desserts.

\section{APSA - 901h Annual Meeting - September 1-4, 1994 • New York City}

